\title{
Optimising the Organic, Inorganic and Biofertiliser Needs for Sustained Productivity of Maize (Zea Mays L.)
}

\author{
Prayasi Nayak*, A. Pratap Kumar Reddy, N. Sunitha and K.V. Naga madhuri
}

Department of Agronomy, Department of Soil Science and Agricultural Chemistry, S.V. Agricultural College, Tirupati, Acharya N.G Ranga Agricultural University, India

*Corresponding author

\begin{tabular}{|l|}
\hline Ke y w o r d s \\
Maize \\
$\begin{array}{l}\text { Zea Mays L., } \\
\text { Organic, Inorganic } \\
\text { and Biofertiliser }\end{array}$ \\
\hline Article Info \\
\hline $\begin{array}{l}\text { Accepted: } \\
\text { 10 March } 2019 \\
\text { Available Online: } \\
\text { 10 April } 2019\end{array}$ \\
\hline
\end{tabular}

\section{A B S T R A C T}

A field experiment was conducted during kharif season of 2017-18 on sandy loam soil of S.V. Agricultural College Wetland Fam, Tirupati campus of Acharya N. G. Ranga Agricultural University to optimise the organic, inorganic and biofertiliser needs for sustained productivity of maize (Zea mays L.). Seven treatments comprising all possible combinations of chemical fertilizer, organic manure (vermicompost, FYM) with and without biofertilizer (Azospirillum and PSB) were laid out in randomized block design with three replications. Nutrient uptake and yield was significantly influenced by the application of organic and inorganic sources of nutrients. Application of $100 \%$ RDF (T1) (180-60-50 kg N, $\mathrm{P}_{2} \mathrm{O}_{5}$ and $\mathrm{K}_{2} \mathrm{O}$ ha $^{-1}$ ) recorded significantly higher nutrient uptake, kernel $\left(5207 \mathrm{~kg} \mathrm{ha}^{-1}\right)$ and stover yield $\left(6751 \mathrm{~kg} \mathrm{ha}^{-1}\right)$. However, 50\% RDF + Vermicompost @ 1t ha-1+Azospirillum @5 kg ha ${ }^{-1}+$ PSB @ $5 \mathrm{~kg} \mathrm{ha}^{-1}$ (T7) has given a remarkable kernel $\left(4683 \mathrm{~kg} \mathrm{ha}^{-1}\right)$ and stover yield $\left(6394 \mathrm{~kg} \mathrm{ha}^{-1}\right)$ wand a higher nutrient uptake which is in turn in parity with 50\% RDF+FYM@5 tha ${ }^{-1}+$ Azospirillum @ 5 kg ha + PSB @ 5 kg $\mathrm{ha}^{-1}$ (T6) and significantly superior to rest of the treatments.

\section{Introduction}

Maize an important food and feed crop of the world, which is often referred to as 'Queen of cereals and miracle crop'. Now-a-days the escalating cost of chemical fertilizers is considerably resulting in lower net returns. Continuous application of fertilizers alone in a system deteriorates soil health and affects crop productivity (Kannan et al., 2013). Although fertilizers supply quick nutrients to the soil, they impede the uptake of other nutrients and there by upset the whole mineral balance pattern. Nutrient management practices that depend lesser on inorganic fertilizers are required to minimize the adverse effects. Integrated nutrient management, which includes potential sources like fertilizers, bulky organic manures and biofertilisers in a balanced proportion could help in mitigating the problems and to build an ecologically as well as economically viable farming system. Organic manures particularly FYM and vermicompost, not only supply macronutrients but also meet the requirement of micronutrients, besides 
improving soil health (Wailare and Kesarwani, 2017). Biofertilisers are the low cost inputs for supplementing the essential plant nutrients to achieve sustainable agriculture. The presence of different microbes, enzymes and hormones enhance the availability of soil inherent nutrients by the formation of organic acids. Hence, massive efforts are to be adopted with integration of organic, inorganic and biological sources of plant nutrients in the developing countries for improvement of soil fertility and productivity (Hashim et al., 2016).

\section{Materials and Methods}

The field experiment was conducted at S.V. Agricultural College Wetland Farm, Tirupati campus of Acharya N. G. Ranga Agricultural University in kharif, 2017. Total rainfall received during the crop growth period was $833.6 \mathrm{~mm}$ in 42 rainy days. The soil of the experimental field was sandy loam in texture, slightly alkaline in soil reaction ( $\mathrm{pH} 7.9)$, low in organic carbon $(0.25 \%)$ and available $\mathrm{N}$ $\left(125 \mathrm{~kg} \mathrm{ha}^{-1}\right)$ and medium in available phosphorus (11.7 $\left.\mathrm{kg} \mathrm{ha}^{-1}\right)$ and available potassium $\left(223.3 \mathrm{~kg} \mathrm{ha}^{-1}\right)$.

The field experiment was laid out in Randomized Block Design (RBD). There were seven treatments and three replications. The treatment details are furnished below

$\mathrm{T}_{1}: 100 \%$ recommended dose of fertiliser $\left(\mathrm{RDF}=180-60-50 \mathrm{~kg} \mathrm{~N}, \mathrm{P}_{2} \mathrm{O}_{5}\right.$ and $\mathrm{K}_{2} \mathrm{O} \mathrm{ha}{ }^{-1}$ )

$\mathrm{T}_{2}$ : FYM@10 t ha ${ }^{-1}+$ Azospirillum @ 5 $\mathrm{kgha}^{-1}+$ PSB@ $5 \mathrm{~kg} \mathrm{ha}^{-1}$

$\mathrm{T}_{3}$ : Vermicompost @ $2 \mathrm{tha}^{-1}+$ Azospirillum @ $5 \mathrm{kgha}^{-1}+\mathrm{PSB} @ 5 \mathrm{~kg} \mathrm{ha}^{-1}$

$\mathrm{T}_{4:} 50 \% \mathrm{RDF}+\mathrm{FYM} @ 5 \mathrm{tha}^{-1}$

$\mathrm{T}_{5:}$ 50\% RDF+Vermicompost @ $1 \mathrm{tha}^{-1}$
T6: $50 \% \mathrm{RDF}+\mathrm{FYM} @ 5 \mathrm{t} \mathrm{ha}^{-1}+$ Azospirillum@5 kg ha ${ }^{-1}+$ PSB@ $5 \mathrm{~kg} \mathrm{ha}^{1}$

$\mathrm{T}_{7}: 50 \% \mathrm{RDF}+$ Vermicompost @ $1 \mathrm{t} \mathrm{ha}^{-1}+$ Azospirillum@5 kg ha ${ }^{-1}+$ PSB @ 5 kg ha ${ }^{-1}$

Farm yard manure and Vermicompost were incorporated in marked plots as per treatments and its composition on dry basis was $0.51 \%$ $\mathrm{N}, 0.25 \% \mathrm{P}_{2} \mathrm{O}_{5}, 0.52 \% \mathrm{~K}_{2} \mathrm{O}$ for FYM and $1.7 \% \mathrm{~N}, 1.1 \% \mathrm{P}_{2} \mathrm{O}_{5}, 1.0 \% \mathrm{~K}_{2} \mathrm{O}$. Full dose of phosphorus $\left(60 \mathrm{~kg} \mathrm{ha}^{-1}\right)$ and potassium $(50 \mathrm{~kg}$ $\left.\mathrm{ha}^{-1}\right)$ in the form of single super phosphate (SSP) and muriate of potash (MOP) were applied as basal dose at the time of sowing. Nitrogen $\left(180 \mathrm{~kg} \mathrm{ha}^{-1}\right)$ in the form of urea was applied as per the treatments in three splits viz., $1 / 3^{\text {rd }}$ as basal, $1 / 3^{\text {rd }}$ at knee high stage and the remaining $1 / 3^{\text {rd }}$ at tasseling stage through band placement. The crop was harvested on 28 october in 2017.

\section{Results and Discussion}

\section{Nutrient uptake}

Different treatments significantly $(\mathrm{P}<0.05)$ influenced nutrient uptake in maize (Table 1). The maximum nitrogen uptake (139 kg ha $\left.{ }^{-1}\right)$ by plant at harvest was recorded with application of $100 \%$ RDF $\left(\mathrm{T}_{1}\right)$, which was significantly superior over rest of the nutrient management practices tried. Recommended levels of nutrient application enhance the nutrient availability at the rhizosphere of the crop, which inturn enables the greater absorption of nutrients. Application of biofertiliser increased the nitrogen uptake by 21 per cent with supply of 50\% RDF + Vermicompost@1 tha ${ }^{-1}+$ Azospirillum @ 5 $\mathrm{kg} \mathrm{ha}{ }^{-1}+$ PSB@ $@ \mathrm{~kg} \mathrm{ha}^{-1}\left(\mathrm{~T}_{7}\right)$ over 50\% $\mathrm{RDF}+$ Vermicompost @ $1 \mathrm{t} \mathrm{ha}^{-1}\left(\mathrm{~T}_{5}\right)$ and by 20 per cent with $50 \%$ RDF + FYM @ $5 \mathrm{t} \mathrm{ha}^{-1}$ +Azospirillum @5 kg ha ${ }^{-1}+$ PSB@ 5 kg ha ${ }^{1}\left(\mathrm{~T}_{6}\right)$ over 50\% RDF + FYM @ $5 \mathrm{t} \mathrm{ha}^{-1}\left(\mathrm{~T}_{4}\right)$. It might be due to promoting effect of 
Azospirillum and their ability to produce biologically active substances, provision of significant amount of available nitrogen through biological nitrogen fixation, improve photosynthesis and promoting root growth which in turn enhances nutrient uptake.

The maximum phosphorus uptake was recorded with application of $100 \% \operatorname{RDF}\left(\mathrm{T}_{1}\right)$, which was significantly superior over rest of the treatments tried (Table 1 and Fig. 1). The lower phosphorus uptake was observed with sole application of organic sources through FYM@10 t ha ${ }^{-1}+$ Azospirillum @ $5 \mathrm{~kg} \mathrm{ha}^{-1}$ + PSB@5 kg ha ${ }^{-1}\left(\mathrm{~T}_{2}\right)$ which was on par with Vermicompost @ $2 \mathrm{t} \mathrm{ha}^{-1}+$ Azospirillum @ $5 \mathrm{~kg} \mathrm{ha}^{-1}+\mathrm{PSB} @ 5 \mathrm{~kg} \mathrm{ha}^{-1}\left(\mathrm{~T}_{3}\right)$. Presence of phosphorus solubilising bacteria in $\mathrm{T}_{7}$ (50\% RDF + Vermicompost @ $1 \mathrm{t} \mathrm{ha}^{-1}+$ Azospirillum@5 kg ha ${ }^{-1}+$ PSB @ $5 \mathrm{~kg} \mathrm{ha}^{-1}$ ) and $\mathrm{T}_{6}\left(50 \% \mathrm{RDF}+\mathrm{FYM} @ 5 \mathrm{t} \mathrm{ha}^{-1}+\right.$ Azospirillum @ $5 \mathrm{~kg} \mathrm{ha}{ }^{-1}+\mathrm{PSB} @$ $5 \mathrm{~kg} \mathrm{ha}^{-1}$ ) resulted in more phosphorus uptake. It might be due to the phosphatic biofertilisers, in the form of micro organisms could have helped in increasing the availability of accumulated phosphates for plant growth by solubilization which inturn enhanced the availability of plant growth substances. These findings are in agreement with Hameeda et al., (2008). The potassium uptake by plant was significantly increased due to the application of entire dose of recommended NPK through fertilizers $\left(T_{1}\right)$ which was significantly superior to all other treatments. Next higher uptake recorded with $50 \% \mathrm{RDF}+$ Vermicompost @ $1 \mathrm{t} \mathrm{ha}^{-1}+$ Azospirillum@5 kg ha ${ }^{-1}+$ PSB @ $5 \mathrm{~kg} \mathrm{ha}^{-1}$ $\left(\mathrm{T}_{7}\right)$ which was however comparable with $50 \% \mathrm{RDF}+\mathrm{FYM} @ 5 \mathrm{t} \mathrm{ha}^{-1}+$ Azospirillum @ $5 \mathrm{~kg} \mathrm{ha}{ }^{-1}+$ PSB @ $5 \mathrm{~kg} \mathrm{ha}^{-1}\left(\mathrm{~T}_{6}\right)$. Critical observations of the data revealed that potassium uptake by the crop was increased with increase in level of nitrogen (Table 1 and Fig. 1), which might be due to the enhanced number of small root hairs which in turn facilitated the absorbing ability per unit dry weight (Sunitha and Reddy, 2012).

Yield

Adequate nutrient management in maize either with inorganic sources or their combined use significantly enhanced kernel and stover yield. Application of $100 \%$ NPK through inorganic sources of fertilizer significantly improved the maize yield $\left(\mathrm{T}_{1}\right)$. The maximum kernel yield (5207 $\mathrm{kg} \mathrm{ha}^{-1}$ ) was obtained with $\mathrm{T}_{1}$ with the application of entire dose of recommended NPK through fertilizers and it was significantly superior to $100 \%$ organic and integrated nutrient management practices (Table 2). The second best treatment was $\mathrm{T}_{7}$ (50\% RDF + Vermicompost @ 1t ha ${ }^{-1}$ +Azospirillum@5 kg ha ${ }^{-1}+$ PSB@ 9 kg ha $\left.{ }^{1}\right)$ which was on par with $\mathrm{T}_{6}(50 \% \mathrm{RDF}+$ FYM@5 t ha ${ }^{-1}+$ Azospirillum @ $5 \mathrm{~kg} \mathrm{ha}^{-1}+$ PSB @ $5 \mathrm{~kg} \mathrm{ha}^{-1}$ ) also recorded higher kernel and stover yield over rest of the treatments. Integrating Azospirillum and PSB along with FYM, Vermicompost and RDF produced remarkable yield compared to sole application of organics. Organic manures like FYM and vermicompost also supply nutrients beneficial to crop growth and productivity. Therefore, substitution of $50 \%$ inorganic fertilizers with Vermicompost / FYM in combination with bio fertilizer had given the kernel yield which was comparable to $100 \%$ RDF. This is in confirmation with the findings of Shah and Wani (2017).

Integration of biofertilizer in treatment $\mathrm{T}_{7}(50$ $\%$ RDF + vermicompost @ 1t ha ${ }^{-1}+$ Azospirillum @ $5 \mathrm{~kg} \mathrm{ha}^{-1}+$ PSB @ $5 \mathrm{~kg} \mathrm{ha}^{-1}$ )

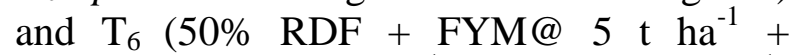
Azospirillum@5 kg ha ${ }^{-1}+$ PSB @ $5 \mathrm{~kg} \mathrm{ha}^{-1}$ ) recorded 19 and 23 per cent more yield compared to $\mathrm{T}_{4}\left(50 \% \mathrm{RDF}+\mathrm{FYM} @ 5 \mathrm{t} \mathrm{ha}^{-1}\right)$ and $\mathrm{T}_{5}(50 \% \mathrm{RDF}+$ Vermicompost @ 1t $\mathrm{ha}^{-1}$ ) which did not include biofertilizer (Fig. 2). 
Table.1 Nutrient (N, P and $\mathrm{K})$ uptake $\left(\mathrm{kg} \mathrm{ha}^{-1}\right)$ by maize as influenced by various nutrient management practices

\begin{tabular}{|c|c|c|c|}
\hline Treatments & N uptake & P uptake & K uptake \\
\hline $\begin{aligned} T_{1}: & 100 \% \text { RDF }\left(180-60-50 \mathrm{~kg} \mathrm{~N}, \mathrm{P}_{2} \mathrm{O}_{5} \text { and }\right. \\
& \left.\mathrm{K}_{2} \mathrm{O} \mathrm{ha}^{-1}\right)\end{aligned}$ & 139 & 37.7 & 128 \\
\hline $\begin{aligned} \mathrm{T}_{2}: & \text { FYM @10 } \mathrm{t} \mathrm{ha}+\text { Azospirillum @ } 5 \mathrm{~kg} \\
& \mathrm{ha}^{-1}+\text { PSB @ } 5 \mathrm{~kg} \mathrm{ha}^{-1}\end{aligned}$ & 76.2 & 18.0 & 73.0 \\
\hline $\begin{aligned} \mathbf{T}_{3}: & \text { Vermicompost @ } 2 \mathrm{t} \mathrm{ha}^{-1}+\text { Azospirillum } \\
& @ 5 \mathrm{~kg} \mathrm{ha}^{-1}+\text { PSB @ } 5 \mathrm{~kg} \mathrm{ha}^{-1}\end{aligned}$ & 78.3 & 19.6 & 75.7 \\
\hline $\mathrm{T}_{4}: 50 \% \mathrm{RDF}+\mathrm{FYM} @ 5 \mathrm{t} \mathrm{ha} \mathbf{a}^{-1}$ & 92.1 & 23.9 & 88.8 \\
\hline $\mathrm{T}_{5}: 50 \%$ RDF + Vermicompost @ $1 \mathrm{t} \mathrm{ha}^{-1}$ & 96.8 & 25.7 & 93.2 \\
\hline 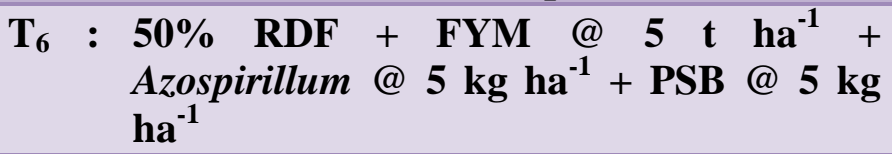 & 115 & 30.5 & 104 \\
\hline $\begin{aligned} \mathrm{T}_{7}: & 50 \% \mathrm{RDF}+\text { Vermicompost @ } 1 \mathrm{t} \mathrm{ha}^{-1}+ \\
& \text { Azospirillum @ } 5 \mathrm{~kg} \mathrm{ha}^{-1}+ \\
& \text { PSB @ } 5 \mathrm{~kg} \mathrm{ha}^{-1}\end{aligned}$ & 123 & 32.8 & 112 \\
\hline SEm \pm & 2.9 & 0.9 & 2.9 \\
\hline $\mathrm{CD}(\mathrm{P}=\mathbf{0 . 0 5})$ & 9.1 & 2.8 & 8.9 \\
\hline
\end{tabular}

Table. 2 Kernel yield, stover yield $\left(\mathrm{kg} \mathrm{ha}^{-1}\right)$ and harvest index of maize as influenced by various nutrient management practices

\begin{tabular}{|c|c|c|c|}
\hline Treatments & $\begin{array}{l}\text { Kernel } \\
\text { yield } \\
\left(\mathrm{kg} \mathrm{ha}^{-1}\right)\end{array}$ & $\begin{array}{l}\text { Stover } \\
\text { yield } \\
\left(\mathrm{kg} \mathrm{ha}^{-1}\right)\end{array}$ & $\begin{array}{l}\text { Harvest } \\
\text { index } \\
(\%)\end{array}$ \\
\hline$T_{1}: 100 \%$ RDF (180-60-50 kg N, $P_{2} O_{5}$ and $\left.K_{2} O h^{-1}\right)$ & 5207 & 6751 & 43.5 \\
\hline $\begin{aligned} \mathrm{T}_{2}: & \text { FYM @10 } \mathrm{tha}^{-1}+\text { Azospirillum @ } 5 \mathrm{~kg} \mathrm{ha}^{-1}+\text { PSB } \\
& @ 5 \mathrm{~kg} \mathrm{ha}^{-1}\end{aligned}$ & 2059 & 4937 & 29.4 \\
\hline $\begin{aligned} \mathrm{T}_{3}: \text { Vermicompost @ } 2 \mathrm{t} \mathrm{ha}^{-1}+\text { Azospirillum @ } 5 \mathrm{~kg} \\
\\
\mathrm{ha}^{-1}+\text { PSB @ } 5 \mathrm{~kg} \mathrm{ha}^{-1}\end{aligned}$ & 2352 & 4950 & 32.2 \\
\hline $\mathrm{T}_{4}: 50 \% \mathrm{RDF}+\mathrm{FYM} @ 5 \mathrm{t} \mathrm{ha}^{-1}$ & 3660 & 5790 & 38.7 \\
\hline $\mathrm{T}_{5}: 50 \% \mathrm{RDF}+$ Vermicompost @ $1 \mathrm{t} \mathrm{ha}^{-1}$ & 3949 & 5815 & 40.5 \\
\hline $\begin{aligned} \text { T }_{6}: & 50 \% \text { RDF + FYM @ } 5 \mathrm{t} \mathrm{ha}^{-1}+\text { Azospirillum @ } 5 \mathrm{~kg} \\
& \mathrm{ha}^{-1}+\text { PSB @ } 5 \mathrm{~kg} \mathrm{ha}^{-1}\end{aligned}$ & 4534 & 6206 & 42.2 \\
\hline $\begin{aligned} \mathrm{T}_{7}: & 50 \% \mathrm{RDF}+\text { Vermicompost @ } 1 \mathrm{t} \mathrm{ha}^{-1}+ \\
& \text { Azospirillum @ } 5 \mathrm{~kg} \mathrm{ha}^{-1}+ \\
& \text { PSB @ } 5 \mathrm{~kg} \mathrm{ha}^{-1}\end{aligned}$ & 4683 & 6394 & 42.2 \\
\hline SEm \pm & 88 & 114 & 0.61 \\
\hline $\mathrm{CD}(\mathrm{P}=\mathbf{0 . 0 5})$ & 271 & 317 & 1.87 \\
\hline
\end{tabular}


Fig.1 Nutrient uptake $\left(\mathrm{kg} \mathrm{ha}^{-1}\right)$ by maize as influenced by various nutrient management practices

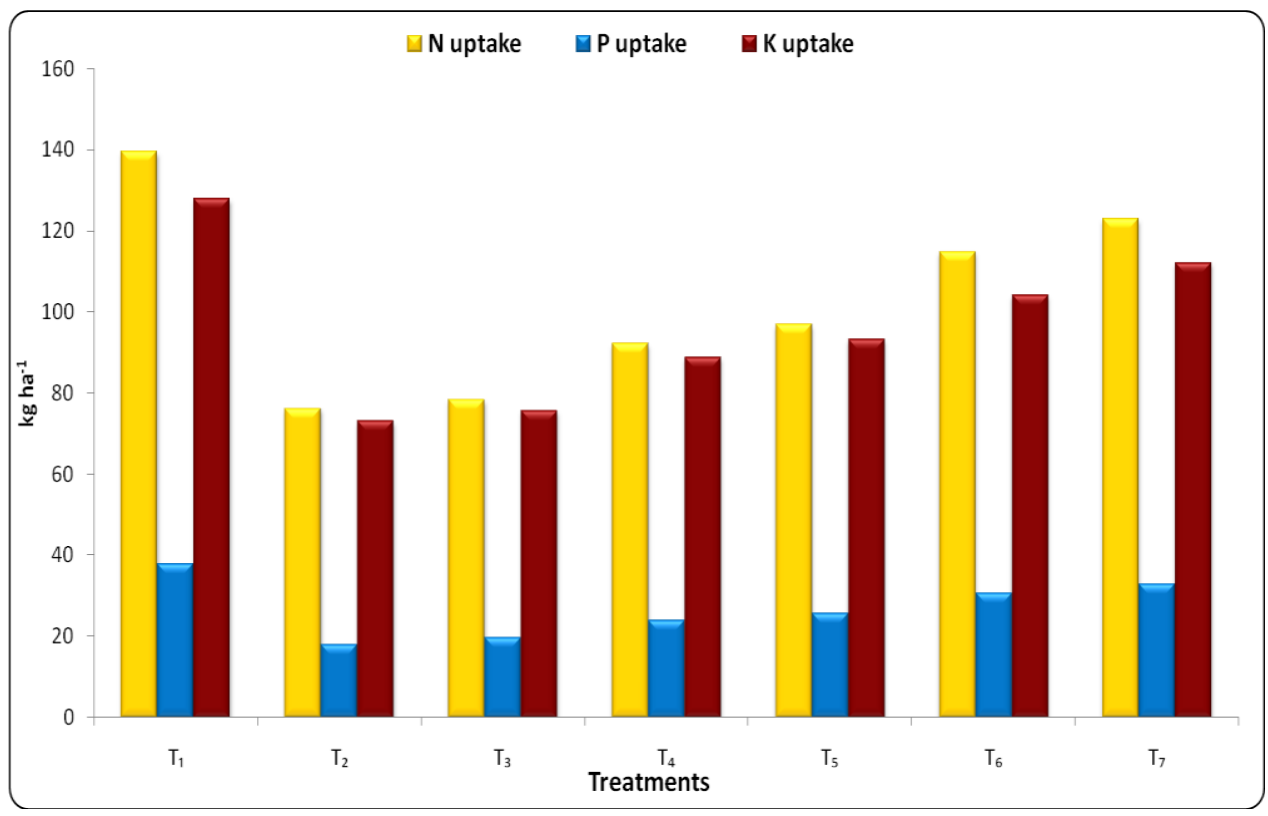

Fig.2 Kernel yield and stover yield $\left(\mathrm{kg} \mathrm{ha}^{-1}\right)$ of maize as influenced by various nutrient management practices

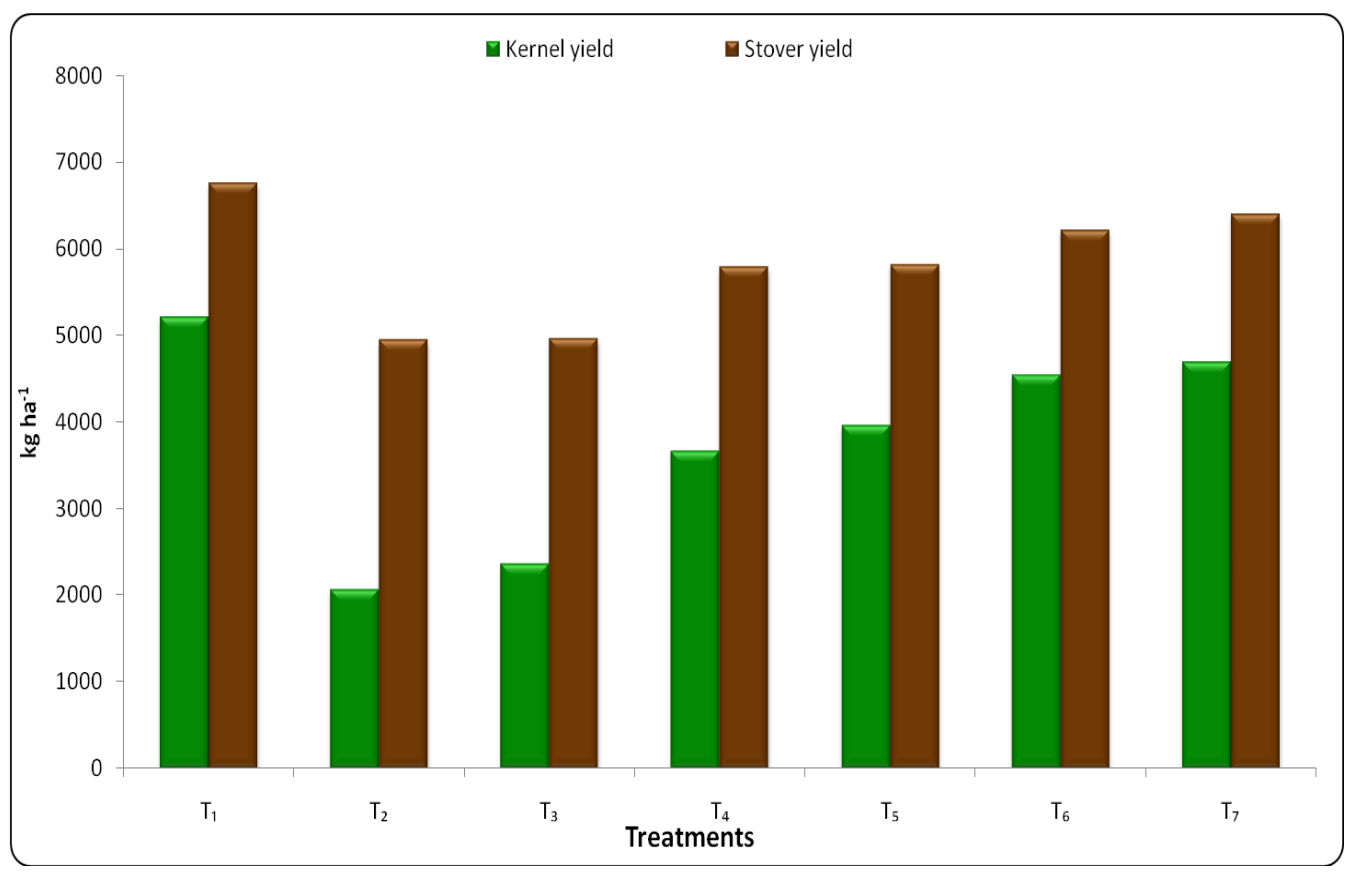

These results are in accordance with the findings of Beigzade et al., (2013) Hashim et al.(2015). and Rasool et al., (2015).
Similar to kernel yield, stover yield was also significantly influenced by different organic and inorganic nutrient management practices. Among all the nutrient management practices, 
higher stover yield of maize $\left(6751 \mathrm{~kg} \mathrm{ha}^{-1}\right)$ was recorded with $100 \%$ RDF $\left(T_{1}\right)$, which was significantly superior over rest of the nutrient management practices tried. Next best treatment was $50 \%$ RDF + Vermicompost @ $1 \mathrm{tha}^{-1}+$ Azospirillum @ 5 $\mathrm{kg} \mathrm{ha}^{-1}+\mathrm{PSB} @ 5 \mathrm{~kg} \mathrm{ha}^{-1}\left(\mathrm{~T}_{7}\right)$ which was in parity with 50\% RDF + FYM @ $5 \mathrm{t} \mathrm{ha}^{-1}+$ Azospirillum@5 kg ha ${ }^{-1}+$ PSB @ $5 \mathrm{~kg} \mathrm{ha}^{-1}$ $\left(\mathrm{T}_{6}\right) . \mathrm{s}$

Stover yield of maize was the combined effect of plant height and dry matter accumulation and both the parameters were found to be higher with the higher level of NPK supplied through $100 \% \operatorname{RDF}\left(\mathrm{T}_{1}\right)$. This might be due to increased availability of essential plant nutrients from the balanced supply of nutrients. Enhanced stover yield is the outcome of the positive and synergistic interaction between the nutrient supply and growth stature of maize as reflected in enhanced growth parameters with supply of the higher optimum dose of NPK with integration of organics and biofertilisers. Similar result was noticed by Tetarwal et al., (2011).

The increase in kernel and stover yield with $50 \% \mathrm{RDF}+$ Vermicompost @ $1 \mathrm{t} \mathrm{ha}^{-1}+$ Azospirillum @ $5 \mathrm{~kg} \mathrm{ha}^{-1}+$ PSB @ $5 \mathrm{~kg} \mathrm{ha}^{-1}$ $\left(\mathrm{T}_{7}\right)$ followed by $50 \% \mathrm{RDF}+\mathrm{FYM} @ 5 \mathrm{tha}^{-1}$ +Azospirillum@5 kg ha ${ }^{-1}+$ PSB @ $5 \mathrm{~kg} \mathrm{ha}$ ${ }^{1}\left(\mathrm{~T}_{7}\right)$ might be due to sufficient amount of the released nutrients by mineralization at a constant level and increased the nutrient uptake under better soil environment that had been created owing to cumulative effect of organic sources combined with inorganic source of nutrients, which in turn improved plant growth and subsequently the kernel and stover yield as reported by Hashim et al., (2015). The lower stover yield (4937 kg ha-1) was recorded with $\mathrm{T}_{2}$ (FYM @ $10 \mathrm{t} \mathrm{ha}^{-1}+$ Azospirillum@ $\left.5 \mathrm{~kg} \mathrm{ha}^{-1}+\mathrm{PSB} @ 5 \mathrm{~kg} \mathrm{ha} 1\right)$ which was on par with $\mathrm{T}_{3}$ (Vermicompost @
$2 \mathrm{tha}{ }^{-1}+$ Azospirillum @ $5 \mathrm{~kg} \mathrm{ha}^{-1}+$ PSB@ 5 $\mathrm{kg} \mathrm{ha}^{-1}$ ) due to poor vegetative growth caused by sub optimum supply of nutrients.

In conclusion, the present study revealed that higher productivity of maize as well as economic returns could be realized with $100 \%$ recommended dose of nutrients through fertilizers i.e. 180-60-50 kg N, $\mathrm{P}_{2} \mathrm{O}_{5}$ and $\mathrm{K}_{2} \mathrm{O}$ $\mathrm{ha}^{-1}$. Among the various integrated nutrient management practices, application of 50\% $\mathrm{RDF}+$ Vermicompost @ $1 \mathrm{t} \mathrm{ha}^{-1}+$ Azospirillum @ $5 \mathrm{~kg} \mathrm{ha}^{-1}+$ PSB @ $5 \mathrm{~kg} \mathrm{ha}^{-1}$ proved to be the most promising and feasible approach for higher yield where as 50\% RDF +FYM @ $5 \mathrm{t} \mathrm{ha}^{-1}+$ Azospirillum @ $5 \mathrm{~kg} \mathrm{ha}^{-1}$ + PSB@ $5 \mathrm{~kg} \mathrm{ha}^{-1}\left(\mathrm{~T}_{6}\right)$ was economically viable, along with maintenance of soil biological activity and fertility for the sustenance of soil ecology. Hence, adoption of a balanced nutrient management approach will safeguard the desire for higher crop productivity with economic returns. Long run adoption of combined use of fertilizers and organics expected to match and even excel the sole fertilizer based production strategy.

\section{References}

Beigzade, M., Maleki, A., Siaddat, S.A and Mohammadi, M.M. 2013. Effect of combined application of phosphate fertilizers and phosphate solubilising bacteria on yield and yield components of maize single cross 704 . International Journal of Agriculture and Crop Sciences 6(17): 1179-1185.

Hameeda, B., Harini, G., Rupela. O.P., Wani, S.P and Reddy, G. 2008. Growth promotion of maize by phosphatesolubilizing bacteria isolated from compost and macrofauna. Microbiological Research. 163: 234242.

Hashim, A.F., Hatim, A.A.A and Soumya, S.M. 2016. Effects of chemical and 
bio-fertilizers on yield, yield components and grain quality of maize (Zea mays L.). African Journal of Agricultural Research. 11(45): 46544660.

Hashim, M., Dhar, S., Vyas, A.K., Pramesh, $\mathrm{V}$ and Kumar, B. 2015. Integrated nutrient management in maize (Zea mays) - wheat (Triticum aestivum) cropping system. Indian journal of Agronomy. 60(3): 352-359.

Kannan, L.R., Dhivya, M., Abinaya, D., Krishna, R.L and Krishnakumar, S. 2013. Effect of integrated nutrient management on soil fertility and productivity in Maize. Bulletin of Environment, Pharmacology and Life Sciences. 2(8): 61-67.

Rasool, S., Kanth, R.H., Hamid, S., Raja, W., Alie, B.A and Dar, Z.A. 2015. Influence of Integrated nutrient management on growth and yield of sweet corn (Zea mays L. saccharata) under temperate conditions of Kashmir Valley. American Journal of Experimental Agriculture. 7(5): 315325.

Shah, R.A and Wani, B.A. 2017. Yield, nutrient uptake and soil fertility of maize (Zea mays L.) as influenced by varying nutrient management practices under temperate conditions of Kashmir valley, India. Plant Archives. 17(1): $75-78$

Sunitha, N and Reddy, P.M. 2012. Effect of graded nutrient levels and timing of nitrogen application on yield and quality of sweet corn. Madras Agricultural Journal. 99(4-6): 240243.

Tetarwal, J.P., Ram, B and Meena, D.S 2011. Effect of integrated nutrient management on productivity, profitability, nutrient uptake and soil fertility in rainfed maize (Zea mays). Indian Journal of Agronomy. 56(4): 373-376.

Wailare, A.T and Kesarwani. A. 2017. Effect of integrated nutrient management on growth and yield parameters of maize (Zea mays L.) As well as soil physicochemical properties. Biomedical Journal of Scientific and Technical Research.

\section{How to cite this article:}

Prayasi Nayak, A. Pratap Kumar Reddy, N. Sunitha and Naga madhuri, K.V. 2019. Optimising the Organic, Inorganic and Biofertiliser Needs for Sustained Productivity of Maize (Zea Mays L.). Int.J.Curr.Microbiol.App.Sci. 8(04): 1203-1209. doi: https://doi.org/10.20546/ijcmas.2019.804.138 